We thank Borge Nordestgaard, Ray Meleady, Mark Roest, Donato Gemmati, Pier Mannucio Mannucci, and Deborah Payne for sending data from their studies for this meta-analysis. We thank Margaret Burke, information scientist, Cochrane Heart Group, for assistance with our searches. We also thank Roger Harbord for his statistical advice.

Contributors: See bmj.com

Funding: All researchers hold permanent positions at the University of Bristol.

Competing interests: None declared.

Ethical approval: Not needed.

1 Ford ES, Smith SJ, Stroup DF, Steinberg KK, Mueller PW, Thacker SB. Homocyst(e)ine and cardiovascular disease: a systematic review of the evidence with special emphasis on case-control studies and nested casecontrol studies. Int J Epidemiol 2002;31:59-70.

2 Brattstrõm L, Wilcken DEL. Homocysteine and cardiovascular disease: cause or effect? Am J Clin Nutr 2000;72:315-23.

Wald DS, Law M, Morris JK. Homocysteine and cardiovascular disease: evidence on causality from a meta-analysis. BMJ 2002;325:1202-6.

4 Davey Smith G, Ebrahim S. 'Mendelian randomization': can genetic epidemiology contribute to understanding environmental determinants of disease? Int J Epidemiol 2003;32:1-22.

5 Homocysteine Lowering Trialists' Collaboration. Lowering blood homocysteine with folic acid based supplements: meta-analysis of randomized controlled trials. BMJ 1998;316:894-8.

6 Wald NJ, Law MR. A strategy to reduce cardiovascular disease by more than 80\%. BMJ 2003;326:1419-23.

7 Klerk M, Verhoef P, Clarke R, Blom HJ, Schouten EG. MTHFR 677C $\rightarrow$ T polymorphism and risk of coronary heart disease. JAMA 2002;288: 2023-31.

8 Davey Smith G, Harbord R, Ebrahim S. Fibrinogen, C-reactive protein and coronary heart disease: does mendelian randomization suggest the associations are non-causal? OJM 2004;97:163-6.

9 Ashfield-Watt PA, Pullin CH, Whiting JM, Clark ZE, Moat SJ, Newcombe RG, et al. Methylenetetrahydrofolate reductase $677 \mathrm{C} \rightarrow \mathrm{T}$ genotype modulates homocysteine responses to a folate-rich diet or a low-dose modulates homocysteine responses to a folate-rich diet or a low-dose folic acid sup

10 Casas JP, Bautista LE, Smeeth L, Sharma P, Hingorani AD. Homocysteine and stroke: evidence on a causal link from mendelian randomisation. Lancet 2005;365:224-32.
11 Shioji K, Kokubo Y, Goto Y, Nonogi H, Iwai N. An association analysis between genetic polymorphisms of matrix metalloproteinase-3 and methylenetetrahydrofolate reductase and myocardial infarction in Japanese. J Thromb Haemost 2004;2:527-8.

12 Yamada Y, Izawa H, Ichihara S, Takatsu F, Ishihara H, Hirayama H, et al. Prediction of the risk of myocardial infarction from polymorphisms in candidate genes. N Engl J Med 2002;347:1916-23.

13 Abu-Amero KK, Wyngaard CA, Dzimiri N. Prevalence and role of methylenetetrahydrofolate reductase $677 \mathrm{C} \rightarrow \mathrm{T}$ and $1298 \mathrm{~A} \rightarrow \mathrm{C}$ polvmorphisms in coronary artery disease in Arabs. Arch Pathol Lab Med 2003; $127: 1349-52$

14 Cronin S, Furie KL, Kelly PJ. Dose-related association of MTHFR 677 allele with risk of ischemic stroke: evidence from a cumulative meta-analysis. Stroke 2005:36:1581-7.

15 Oi S. Current status of prenatal management of fetal spina bifida in the world: worldwide cooperative survey on the medico-ethical issue. Child Nerv Syst 2003;19:596-9.

16 Taguchi H, Kobayashi M, Yoshino N, Hosokawa K. Do Japanese take more folate from traditional Japanese dish than is conventionally estimated? Actual folate contents in hospital diets and marketed lunch boxes. Asian Pacific J Cancer Prev 2004;5:374-8.

17 Dusitanond P, Eikelboom JW, Hankey GJ, Thom J, Gilmore G, Loh K, et al. Homocysteine-lowering treatment with folic acid, cobalamin, and pyridoxine does not reduce blood markers of inflammation, endothelia dysfunction, or hypercoagulability in patients with previous transent

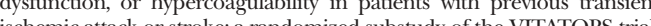
Stroke 2005;36:144-6.

18 Spoelstra-de MA, Brouwer CB, Terheggen F, Bollen JM, Stehouwer CD, Smulders YM. No effect of folic acid on markers of endothelial dysfunction or inflammation in patients with type 2 diabetes mellitus and mild hyperhomocysteinaemia. Neth J Med 2004;62:246-53.

19 Toole J, Malinow MCL, Spence J, Pettigrew L, Howard V, Sides E, et al. Lowering homocysteine in patients with ischemic stroke to prevent recurrent stroke, myocardial infarction and death: the vitamin intervention for stroke prevention (VISP) randomized controlled trial JAMA 2004;291:565-75.

20 Baker F, Picton D, Blackwood S, Hunt J, Erskine M, Dyas M, et al. Blinded comparison of folic acid and placebo in patients with ischaemic heart disease: an outcome trial. Circulation 2002;106(suppl II):741S

21 Davey Smith G, Ebrahim S. Folate supplementation and cardiovascular disease: a familiar story. Lancet 2005; in press.

22 Minelli C, Thompson JR, Tobin MD, Abrams KR. An integrated approach to the meta-analysis of genetic association studies using mendelian randomization. Am J Epidemiol 2004;160:445-52. (Accepted 19 August 2005)

doi 10.1136/bmj.38611.658947.55

\title{
bmjlearning.com
}

\section{The hidden curriculum}

When I started working as a house officer there was no curriculum. One year later, the hospital where I worked had laid out a basic outline of what senior house officers should learn. We were to learn how basic sciences applied to medicine and clinical skills. But six months later, after many no-shows by tutors and trainers, we learnt that the curriculum was a dry piece of paper and nothing more. In contrast, the hidden curriculum was living and breathing (if unwritten): it outlined how to teach (don't bother), how to learn (on your own), and the role of the patient in medical education (a useful and silent prop). There are no prizes for guessing which curriculum we followed.

Traditionally, medical curriculums have had a bad name. But Modernising Medical Careers think that they can do better. 'They've laid out a curriculum for doctors passing through their foundation years and outlined the knowledge, skills, and attitudes that these doctors should learn. They have also outlined how trainers should assess their juniors-by using objective assessment scales such as DOPS (direct observation of procedural skills). ${ }^{2}$ But the new curriculum has its critics: they say that it will take forever to do the assessments and that it is just an exercise in form filling. Modernising Medical Careers reply that the assessment tools are validated and reliable. You can argue either way, but for once there is new money to back up this new curriculum-£73m, and it is ring fenced.

What role does BMJ Learning play in all this? We feel that any new learning initiative will live or die on the learning resources that it provides-in other words, good content is king. So we have produced learning modules to enable juniors to satisfy the generic aspects of the curriculum such as how to work in a team. However, our users have consistently asked for learning modules on the acute care aspect of the curriculum. One of these new modules is on the diagnosis and treatment of acute coronary syndrome. It concentrates on recent developments-such as the role of troponins in diagnosis and assessment of future risk, and the increasing evidence that primary coronary angioplasty (where it's available) is the treatment of choice for patients with an acute myocardial infarction. To find out more, just go to our website, www.bmjlearning.com.

Kieran Walsh clinical editor, BMJ Learning

(bmjlearning@bmjgroup.com)

1 Modernising Medical Careers. www.mmc.nhs.uk/ (accessed 12 May 2005).

2 BMJ Learning. DOPS (direct observation of procedural skills). www.bmjlearning.com/planrecord/assessment/dops.jsp (accessed 12 May 2005). 